\title{
Developing a Program to Strengthen Learning Leadership of School Principals under the Secondary Educational Service Areas
}

\author{
Aphisayarat Prarasri ${ }^{1}$, Amnaj Chanawongse ${ }^{1} \&$ Kowat Tesaputa $^{2}$ \\ ${ }^{1}$ Faculty of Education, Mahasarakham University, Thailand \\ ${ }^{2}$ Faculty of Education, Roi Et Rajabhat University, Thailand \\ Correspondence: Aphisayarat Prarasri, Faculty of Education, Mahasarakham University, Thailand. Tel: \\ 668-8571-9299. E-mail: aphisayarat@gmail.com
}

Received: July 13, 2018

doi:10.5539/ies.v11n12p86
Accepted: September 30, 2018

Online Published: November 27, 2018

URL: https://doi.org/10.5539/ies.v11n12p86

\begin{abstract}
The purpose of this research was to develop the program on learning leadership strengthening for school principals under the secondary educational service areas. This study methodology was based on research and development (R\&D) approach by the application of Participatory Action Research (PAR) with 4 phases. They were 1) finding the components and indicators of learning leadership, 2) study of the present and desirable condition of learning leadership, 3) developing learning leadership strengthening model, and 4) study of the implementation results program of learning leadership strengthening for school principals under the secondary educational service areas. The research findings reveal the program development comprises 70:20:10 ratio of learning leadership development -70 percent on the job experience and off the job experience, 20 percent professional learning community (PLC) process and personal feedback, and 10 percent training. The training involves 3 phases - phase 1 is training, phase 2 is integration with work practice, and phase 3 is follow up and evaluation.
\end{abstract}

Keywords: developing a program, learning leadership, school principals

\section{Introduction}

\subsection{Rationale}

At present knowledge in many fields has been developed rapidly especially on technology that learning must adapt to this rapid change. Learning is not only knowledge transmission from teacher to student as being called Education 1.0 in the past. Education 2.0 involves technology as teaching aid but students have not achieved the intended development results. At present Education 3.0 embraces encouragement for self-learning by various teaching media — printed and digital — with integration of team learning, integrative learning, and social media use. While the progress of technology and knowledge transfer have been at endless accelerated pace, teacher needs self-development to enter the new world of learning and improve teaching process to be in line with new learning behavior. This is very challenging to teacher. The new learning society emphasizes learner not only receiver of knowledge but innovation creator. This is the turning point for teacher to cross the Education 3.0 border line to the new teaching system or Education 4.0. This new educational system relies on constructivism learning to encourage learning to find knowledge from one's experience. Therefore teacher has the critical role for transformation to this innovative teaching (Learning Innovation Center, Chulalongkorn University, 2014).

Successful organizations in the 21 st Century need competent leaders to bring the organization to their goals and to be able to compete with other organizations. In this world of borderless information, the characteristics of leaders are celebrity, systematic thinking, changer, service-based, technological leader, and most significantly committed to learning. Learning leadership therefore is undoubtedly important in today's world and must be developed prior to create learning organization (Marquardt, 2000: 233; Brown \& Posner, 2001, p. 275).

Those who possess learning leadership focus on strategic planning and strategic thinking to upgrade learning achievement of students to develop school to higher quality or effectiveness. School administrators with learning leadership transform leadership role from controlling school effectiveness to facilitate others with emphasis on coaching and supervising to school staff. They seek new knowledge to improve their tasks. They are learning individuals who always find ways to strengthen their professional leadership. They rely on information for decision making and employ resources creatively. Learning leadership depends on inspiration building and 
persuasion to lead others develops knowledge, experience and skills (Neuman \& Simmons, 2000; Deborah, 2002, pp. 61-63).

\subsection{Research Problems}

Secondary schools are basic education institutes that provide learning from junior to high school level. The main mission is to provide learning according to curricula. But the Ordinary National Educational Test (O-NET) results of BE 2558 (AD 2015) from National Institute of Educational Testing Service (Public Organization) found that Thai students in Mathayomsuksa 3 (Grade 9) and Mathayomsuksa 6 (Grade 12) scored the averages of 37.91 and 34.81 percent respectively (NEITS, 2016). Therefore it's the responsibility of school principals to find ways to develop and upgrade students to higher learning to achieve school quality, increase higher learning achievements and develop school staff for life-long learning. School leaders resort to self-leadership with long life continuous learning. They find various models and strategies for learning. They create shared vision with staff based on learning, teamwork, and closed relationship. The strengthening of learning leadership in school is therefore necessary road to develop school to sustainable learning organization (Coad \& Berry, 1998, p. 165; Northouse, 2012; Roueche et al., 2013).

Therefore, having the development program on learning leadership strengthening for school principals under the secondary educational service areas will give school principals the opportunity to enhance learning leadership. This learning would bring development on academic achievements in school and on the educational quality of the country.

\section{Literature Review}

\subsection{Participatory Action Research}

Participatory Action Research (PAR) is an interesting method for researchers in education and education practitioners. They can learn new knowledge and understanding on educational problems and various problem-solving choices on teaching profession development. So the PAR method is a major concept to develop today's profession and problem solving (Johnson, 2012; Mills, 2011; Kemmis, McTaggart, \& Nixon, 2014; Kangpheng \& Kunlong, 2015; Paso, Chantarasombat \& Tirasiravech, 2017).

Therefore, PAR emphasizes on participation and collaboration. In the group working, the participating researchers are equally important and have equal roles in all the research processes in the theoretical concept presentation, action and research policy. PAR is action-oriented to implement change and the study of the results for development. PAR relies on critical function and detailed action. The observed research activities lead to reasonable decision making to adjust implementation plan. The action research spiral is used to develop characteristics, capacity and individual behavior in shared planning, shared design, shared implementation and shared measurement towards satisfactory goal (Kemmis, McTaggart, \& Nixon, 2014).

\subsection{Learning Leadership}

Learning leadership emphasizes on leader's first priority in learning and creating systematic learning opportunity with continuous reinforcement. Leaders should have cognitive power and learning readiness to develop personal capacity for technical or management authority (Kouzes \& Posner, 2016; McCloskey, 2014) Leaders create team capacity from shared learning and collaboration. Coaching is therefore is the key component for professional development based on research and practice according to distributed leadership and teacher capacity building for sustainability. Distributed leadership and coaching in teacher professional development activities are the main responsibility of educator with learning leadership. The person can be teacher with informal leadership or principal with formal leadership (Curtis, 2012).

Therefore, learning leadership is the demonstrable characteristics, capacity, and behavior in creativity and courage, self-directed learning, team learning, employing facilitating technology and innovation learning in digital era, integrating pluralism, and context-oriented transformation. These learning leadership components help push for organization learning, promotion of learning culture, and power distribution for mutual learning with the ultimate goal of sustainable learning organization (Kouzes \& Posner, 2016; Wick, Pollock, \& Jefferson, 2010; Guskey, 2016).

\section{Objective}

Purposes of the study are as follows:

1) To study the components and indicators of the learning leadership of school principals under the secondary educational service areas.

2) To explore the present and desirable condition of school principals under the secondary educational service 
areas.

3) To develop development program on learning leadership strengthening for school principals under the secondary educational service areas.

4) To study results of the implementation of development program on learning leadership strengthening for school principals under the secondary educational service areas.

\section{Method}

This study methodology was based on research and development (R\&D) approach by the application of Participatory Action Research (PAR) with 4 phases as shown in Figure 1 below.

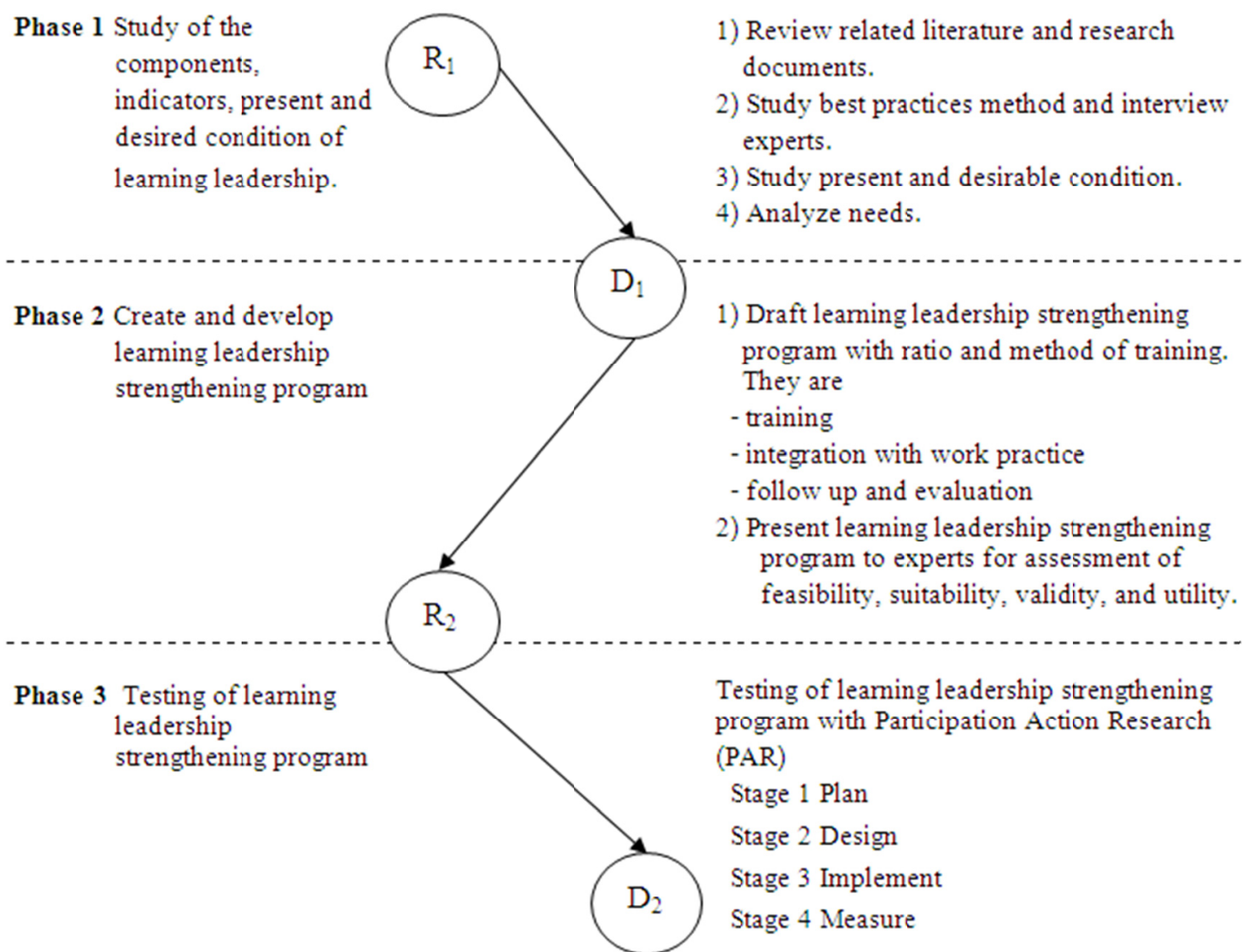

Phase 4 Monitor and evaluation and present learning leadership strengthening program
1) Supervise and monitor results of leaming leadership strengthening program on school principals

2) Conduct focus group discussion for evaluation of leaming leadership strengthening program in 5 levels.

- participants' reaction

- participants' leaming

- organization support and change

- participants' satisfaction

3) Create handbook of leaming leadership strengthening program on school principals

Figure 1. Research phases 


\section{Data Collection}

\subsection{Program Development}

The researchers explored components and indicators of learning leadership with related literature and research documents and with multi case study of learning leadership best practices from 7 educational institutes. The resulted components, indicators and method of learning leadership strengthening were used for data collecting tool on present and desirable condition of learning leadership. The sample of 410 school principals under the secondary school service areas was derived with multi-stage sampling method. The data were analyzed with average, standard deviation statistics together with needs analysis by Priority Needs Index ( $\left.\mathrm{PNI}_{\text {modified }}\right)$.

The researchers drafted the program with data from Phases 1-2 and asked 9 experts on theory and practice to consider feasibility, suitability, validity, and utility.

The researchers then tested the program with implementation on the model to 18 secondary school principals who volunteered to undergo 150 hours of training. The evaluation of the entire program was conducted with 5 level assessments (Guskey, 2016). The levels were participants' reaction, participants' learning, organization support and change, participants' use of new knowledge and skills, and participants' satisfaction.

\subsection{The Participatory Action Research}

The stages of the activities were as follows:

Stage 1: Plan. It included pre self-assessment and defining intended outcomes and objectives.

Stage 2: Design. It included identifying or developing content for the issue/topic, developing the activities and plans for delivery.

Stage 3: Implement. It included acting and conducting PLC process, and after action review.

Stage 4: Measure. It included lesson learned and knowledge sharing.

\section{Results}

The following results of the study, respective of the research objectives, are as follows:

1) Components and indicators of learning leadership of school principals under the secondary school service areas. There are 6 components - creativity and courage, self-directed learning, team learning, integrating pluralism, employing facilitating technology and innovation learning in digital era, and context-oriented transformation. There are 21 indicators among the six components.

2) School principals under the secondary education service areas have learning leadership at medium level $(\bar{X}$ $=3.24)$, need desirable condition at high level $(\overline{\mathrm{X}}=4.38)$ and have needs indices for learning leadership strengthening at high level for all components $\left(\mathrm{PNI}_{\text {modified }}=0.319-0.380\right)$.

3) the development program on learning leadership strengthening for school principals under the secondary educational service areas defines ratio of leadership learning enhancement as 70:20:10 - 70 percent on the job experience and off the job experience, 20 percent on strengthening with professional learning community (PLC) process and personal feedback, and 10 percent on training. The program involves 3 phases - phase 1: training, phase 2: integration with work practice, and phase 3: follow up and evaluation. The evaluation on program evaluation finds that it has the feasibility $(\overline{\mathrm{X}}=4.81)$, suitability $(\overline{\mathrm{X}}=4.77)$, validity $(\overline{\mathrm{X}}=4.59)$ and utility $(\overline{\mathrm{X}}=4.75)$ at highest level in all dimensions.

4) The evaluation of learning leadership strengthening program of school principals under the secondary school service areas reveals that the participants' reaction is at highest level $(\bar{X}=4.64)$, participants' learning is at highest level $(\overline{\mathrm{X}}=4.58)$, organization support and change is at highest level $(\overline{\mathrm{X}}=4.65)$, participants' use of knowledge or skill is at highest level $(\overline{\mathrm{X}}=4.56)$, and participants' satisfaction is at highest level $(\overline{\mathrm{X}}=4.55)$. Below are the phases of training program (Figure 2). 


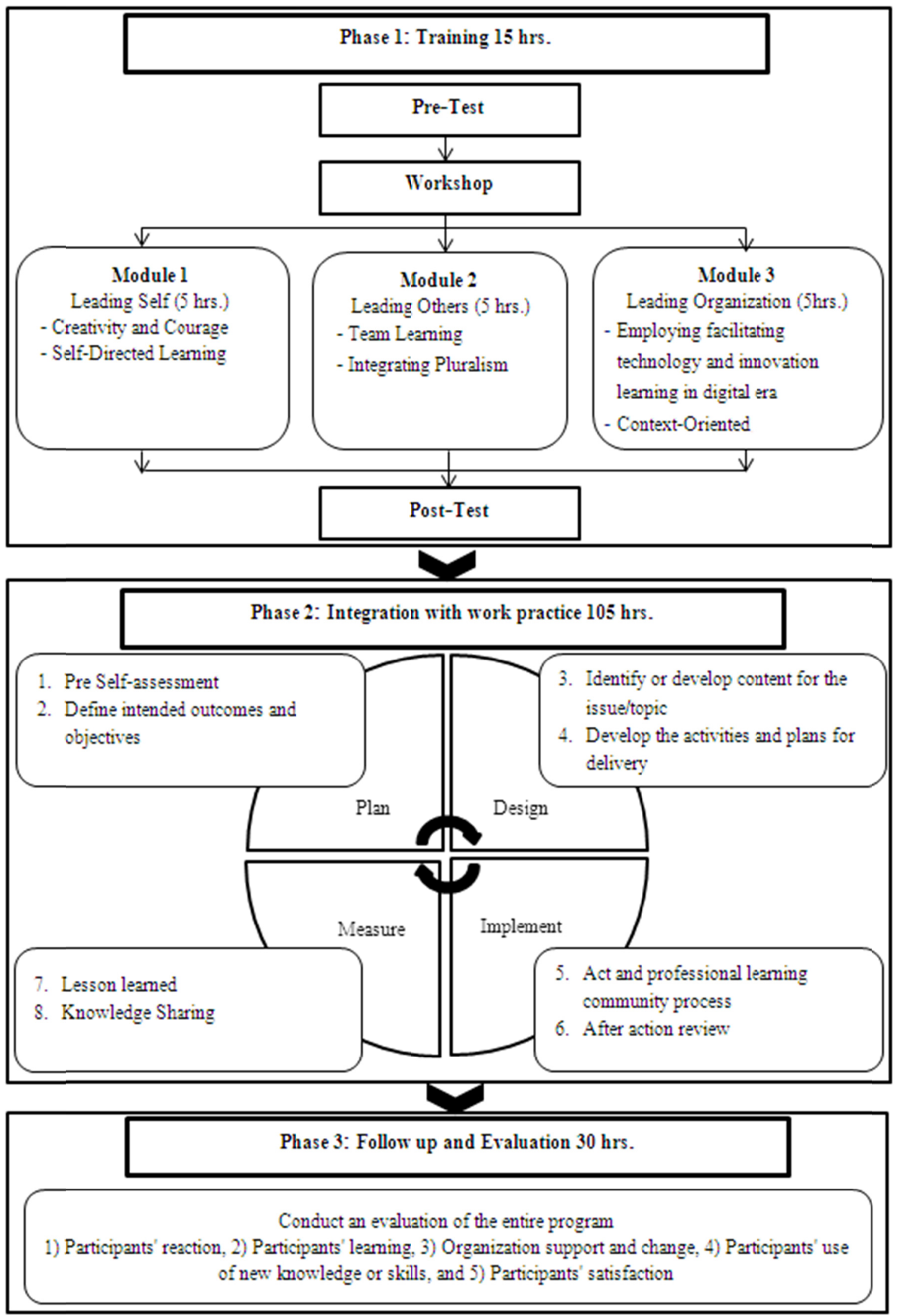

Figure 2. Program to strengthen learning leadership of secondary school principals 


\section{Discussions}

From the research results on the program development on learning leadership strengthening for school principals under the secondary educational service areas, there are discussion issues as follow:

1) The literature and research document review together with 7 leadership learning best practices multi case study results in 6 components - creative and courage, self-directed learning, team learning, integrating pluralism employing facilitating technology and innovation learning in digital era, and context-based oriented transformation. Those components cover the dimensions of leading self, leading others and leading organization (Kangpheng, et al., 2014; Lokkesmoe, 2009; Osland, 2010; Konyu-Fogel 2011; Executive Leadership Development Center, 2013; Stetson University, 2013; Hemdemhall et al., 2013). Therefore the components are adequately suitable in the present globalization leadership concept.

2) The results of program development reveal 70:20:10 development approach-70 percent on the job experience and off the job experience, 20 percent on strengthening with professional learning community (PLC) process and personal feedback, and 10 percent on training. The 150 hours training program is assessed as feasible, suitable, valid, and useful, all at high levels. These results can be explained that the development method help participants to learn and appreciate all the dimensions of learning leadership -- on the job experience, off the job experience, and PLC process. The process includes mentoring, coaching, and personal feedback. These results are also in line with Phillips and Schmidt (2004) who state that the most effective leadership training method should follow 70:20:10 ratio -70 percent from on the job experience, only 20 percent from mentoring, coaching and or personal feedback, and 10 percent form education/training. The results also follow the framework from Marquette University (2017) that leadership training program comprises 3 levels -- individual, group, and community.

Rabin (2014) also presents 70-20-10 model. He defines leadership development as formal and informal with 10:90 ratio. The informal leadership development includes 70 percent learning from experience and practice, and 20 percent from encouragement and support from others. The other 10 percent is from formal learning such as education. This is in line with Kangpheng and Kunlong (2016), Kangpheng (2017) that state curriculum leadership development model in the 21 st Century as comprising 3 dimensions - 9 values ( $9 \mathrm{Cs}$ ), 3 components of curriculum leadership development, and 70:20:10 development method.

Besides, the integration with work practice is defined with development cycle. They are planning, design, development activities, implementation, and evaluation. The participants share learning and self-analysis in order to plan development for continuous cycle of sustainability. This is also in line with Ripley et al (2014) stating that quality education program must include shared working and shared reflection as continuous cycle - plan, design, implement, and measure. Therefore, this cycle is significant for school principals to act continuously for strengthening sustainable learning leadership.

\section{Recommendations}

\subsection{Recommendation for Implementation}

1) Before implement this development program, school principal should set the meeting to explain and persuade school staff for using the program. The program stages must be performed actively and transparently. Suggestions from operators should be welcomed to foster engagement and friendship.

2) Before program implementation stakeholders should engage in understanding work guidelines clearly. Multi development process and sharing such as participatory action research.

3) The process activities according to the development program must be followed completely and continuously as a circle. For example the cycle can start with giving introductory knowledge followed by integration in practice, and monitoring and evaluation.

4) The Office of Basic Education Commission should define education quality on learning leadership of school principals and support research funding for each secondary school service area including best practices selection in each area.

\subsection{Suggestion for Further Research}

1) This research was limited to school principals under the secondary school service areas. Further research should be done in other contexts such as different sized schools or different education agencies.

2) Further research can be done on each detail of components of learning leadership strengthening development program. They can be leading self, leading others, or leading organization.

3) The Participatory Action Research (PAR) or mixed methods research method should be used for enhancing 
learning leadership on school principals for Education 4.0.

\section{References}

Brown, L. M., \& Posner, B. Z. (2001). Exploring the relationship between learning and leadership. The Leadership \& Organization Development Journal, 22(6), 274-280. https://doi.org/10.1108/01437730110403204

Curtis, T. A. (2012). Leading and learning: Leadership, change, and challenge in a professional development $\begin{array}{lllll}\text { initiative } & \text { (Order } & \text { No. 3504009). } & \text { Retrieved }\end{array}$ http://search.proquest.com/docview/1010625210?accountid=44809

Executive Leadership Development Center. (2013). Leadership training program. Retrieved from http://www.deonetraining.com

Guskey, T. R. (2016). Gauge Impact with 5 Levels of Data. Journal of Staff Development, 37(1), 32-37. Retrieved from http:/tguskey.com/wp-content/uploads/Professional-Learning-1-Gauge-Impact-with-FiveLevels-of-Data.pdf

Hemdemhall, M. E., Osland, J. S., Bird, A., Oddou, G. R., Maznevski, M. L., Stevens, M. J., \& Stahl, G. K. (2013). Global leadership: Research, practice, and development (2nd ed.). New York, NY: Routledge.

Johnson, A. P. (2012). A short guide to action research (4th ed.). Upper Saddle River, NJ: Pearson Education.

Kangpheng, S. (2017). Curriculum leadership: Strategies for development and implementation. Mahasarakham: Apichat Printing.

Kangpheng, S., \& Kunlong, S. (2015). Participatory action research. Maha Sarakham: The Degree of Doctor of Philosophy in Educational Management for Local Development, Rajabhat Maha Sarakham University.

Kangpheng, S., \& Kunlong, S. (2016). The curriculum leadership development model for the 21st century: CLD model. Mahasarakham: Apichat Printing.

Kangpheng, S., Kunlong, S., \& Chusorn, P. (2014). Global leadership: Concept and research (2nd ed.). Mahasarakham: Apichat Printing.

Kemmis, S., McTaggart, R., \& Nixon, R. (2014). The action research planner: Doing critical participatory action research. https://doi.org/10.1007/978-981-4560-67-2

Konyu-Fogel, G. (2011). Exploring the effect of global mindset on leadership behavior: An empirical study of business leaders in global organizations. The degree of Doctor of Business Administration, Lawrence Technological University College of Management.

Kouzes, J. M., \& Posner, B. Z. (2016). The leadership challenge: How to get extraordinary things done in organizations. United States of America: Jossey-Bass.

Lokkesmoe, K. J. (2009). A grounded theory study of effective global leadership development strategies: Perspectives from brazil, India, and Nigeria. The Degree of Doctor of Philosophy, The University of Minnesota.

Marquardt, M. (2000). Global leaders for the 21St century. Albany: SUNY Press.

Marquette University. (2017). Leadership development model. Retrieved from http://www.marquette.edu/dsa/leadership/model.shtml

McCloskey, M.W. (2014). Learning leadership in a changing world: Virtue and effective leadership in the 21st century. New York, NY: Palgrave Macmillan. https://doi.org/10.1057/9781137476371

Mills, G. E. (2011). Action research: A guide for the teacher researcher (4th ed.). Boston: Pearson.

National Institute of Educational Testing Service (Public Organization). (2018). Summary of the ordinary national basic educational test (O-net) Academic Year 2560. Retrieved from http://www.newonetresult.niets.or.th/AnnouncementWeb/Login.aspx

Neuman, M., \& Simmons, W. (2000). Leadership for student learning. Phi Delta Kappa, 82(1), 9-12. https://doi.org/10.1177/003172170008200105

Northouse, P. G. (2012). Introduction to leadership: concepts and practice (2nd ed.). Thousand Oaks, CA: Sage.

Osland, J. S. (2010). Expert cognition and sense-making in the global organization leadership context: A case study. In U. Fisher, \& K. Moser (Eds.), Informed by Knowledge: Expert performance in complex situations (pp. 23-40). New York, NY: Taylor \& Francis. 
Paso, C., Chantarasombat, C., \& Tirasiravech, W. (2017). Strengthening teacher's learning management for self-reliance of students in Thai secondary school. International Education Studies, 10(3), 165-175. https://doi.org/10.5539/ies.v10n3p165

Phillips, J. J., \& Schmidt, L. (2004). The leadership scorecard. Burlington, MA: Elsevier Butterworth-Heinemann. https://doi.org/10.1016/B978-0-7506-7764-6.50005-X

Ripley, J., Cummings, S, Lockett, L., Pope, P., Wright, M., Payne, M., ... Murphrey, T. (2014). Creating excellent programs. Retrieved from http://agrilifecdn.tamu.edu/excite/files/2014/06/E3452.pdf

Robin, R. (2014). Blended learning for leadership The CCL approach. Center for creative leadership white paper.

Sinlarat, P. (2016). Education 4.0 is more than education. Annual Academic Seminar of the Teacher's Council 2016 on the topic of Research of the Learning Innovation and Sustainable Educational Management. Bangkok: The Secretariat Office of Teacher's Council.

Stetson University. (2013). Global leadership program. Applications for Spring 2014 are due on October 15, 2013. Retrieved from http://www.stetson.edu/ administration/vibrancy/globalleadership.php

Wick, C., Pollock, R., \& Jefferson, A. (2010). The six disciplines of breakthrough learning: How to turn training and development into business results. San Francisco, CA: Pfeiffer.

\section{Copyrights}

Copyright for this article is retained by the author(s), with first publication rights granted to the journal.

This is an open-access article distributed under the terms and conditions of the Creative Commons Attribution license (http://creativecommons.org/licenses/by/4.0/). 